\title{
DANA INFAK SEBAGAI PONDASI KEUANGAN MASJID NAMIRA LAMONGAN 1
}

\author{
Hengky Asmarakandi \\ Departemen Ekonomi Syariah - Fakultas Ekonomi dan Bisnis - Universitas Airlangga \\ Email: hengkyasmarakandi@gmail.com \\ Noven Suprayogi \\ Departemen Ekonomi Syariah - Fakultas Ekonomi dan Bisnis - Universitas Airlangga \\ Email: Noven2005@gmail.com
}

\begin{abstract}
:
The background of this research is the existence of zero infak phenomenon in Namira Lamongan mosque. This phenomenon encourages researchers to take research that discusses the financial management strategies used until the manager is brave in applying zero infak system. This research uses qualitative approach with case study strategy. Data collection is done through interviewing techniques with related parties and the documents concerned. Analytical techniques carried out in this research are the technique of source triangulation, pattern matching techniques, and descriptive qualitative analysis techniques. The results of this study indicate that the financial management strategy relies on the founders who are usually referred to as yayasan. The phenomenon of zero infak Namira mosque occurs because the mosque's expenditure is too large compared infak income. So the yayasan fund becomes the main role in covering all the shortcomings.
\end{abstract}

Keywords: infak, financial management, mosque finance, Namira Lamongan Mosque.

\section{PENDAHULUAN}

Masjid merupakan sebuah tempat istimewa bagi masyarakat beragama islam. Sebuah tempat dimana umat islam berkumpul dan menjalankan kewajibannya untuk beribada kepada yang Maha Segalanya. Seperti yang tertulis di dalam QS. At-Taubah ayat 18 yang berbunyi :

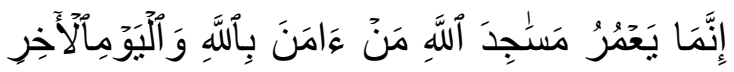

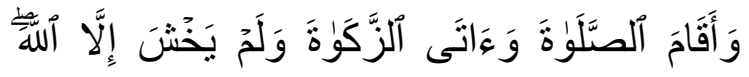

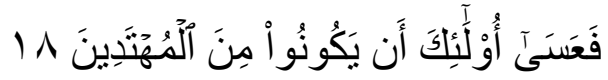
innamaa ya'muru masaajida allaahi man aamana biallaahi waalyawmi al-aakhiri wa-aqaama alshshalaata waaataa alzzakaata walam yakhsya illaa allaaha fa'asaa ulaa-ika an yakuunuu mina almuhtadiina.

Artinya: "hanya yang memakmurkan masjid-masjid Allah ialah orang-orang yang beriman kepada Allah dan hari Kemudian, serta tetap mendirikan shalat, menunaikan zakat dan tidak takut (kepada siapapun) selain kepada Allah, Maka merekalah orang-orang yang diharapkan Termasuk golongan orangorang yang mendapat petunjuk. "

Dari ayat tersebut kita dapat mengetahui bahwa setiap orang yang beriman pasti akan berusaha untuk memakmukan masjid dalam bentuk kegiatan ibadah seperti mendirikan sholat, membayar zakat, i'tikaf, dan sebagainya.

\footnotetext{
${ }^{1}$ Jurnal ini merupakan bagian dari skripsi Hengky Asmarakandi, NIM: 04151 1433082, yang diuji pada tanggal 25 Juni 2019.
} 
Selain jumlah penduduk muslim yang tinggi, Indonesia merupakan Negara yang memiliki jumlah masjid terbanyak di dunia. Berdasarkan data yang ada di simas.kemenag.go.id jumlah masjid hingga saat ini di Indonesia sebanyak 220.571 masjid. Jumlah tersebut terdiri dari 30 masjid raya, 367 masjid agung, 3.943 masjid besar, 182.028 masjid jami, 732 masjid bersejarah, 33.471 masjid publik. Apabila masjid dikelola dengan baik maka akan memberikan dampak terhadap kemakmuran masyarakat secara luas.

Masjid pertama yang dibangun oleh umat islam adalah masjid Quba. Sebuah masjid yang didirikan oleh Rasulullah beserta para sahabat pada tanggal 8 Rabiul Awal 1 Hijriyah. Berbeda dengan masjid yang ada seperti pada zaman sekarang, masjid Quba dibangun dengan bahan-bahan yang sederhana dan seadanya. Hal ini menunjukkan bahwa tidak menjadikan megah dan mewah sebagai prioritas dalam pembangunannya, melainkan untuk mempercepeat proses pendirian masjid Quba agar apat menjadi pusat pembangunan di masyarakat sekitar. Kisah tersebut memberikan kita wawasan bahwa masjid dibangung bukan untuk didirikan dengan kemewahan dan kemegahan, melainkan bagaimana masjid tersebut dapat memberikan dampak positif bagi masyarakat di sekitar serta berjalan sesuai fungsinya sebagai pusat pemberdayaan. Seiring berkembangnya zaman, kehidupan masyarakat menjadi kompleks dan aktivitas masyarakat semakin beragam. kondisi ini tidak dapat disamakan dengan kondisi saat di zaman Rasulullah yang masih sangat sederhana. Keadaan ini menjadi salah satu faktor yang menjadikan masjid di zaman sekarang sepi akan jamaah. Bahkan saat ini kebanyakan masyarakat menganggap bahwa masjid hanya tempat untuk sholat saja. Semakin hari masjid kehilangan fungsinya sebagai pusat peradaban masyarakat.

$$
\text { Kemajuan sebuah masjid }
$$
tergantung pada masyarakat di sekitar masjid tersebut khususnya pengelola yang biasa disebut dengan takmir masjid. Setiap masjid pasti memiliki takmir atau pengurus yang merawat masjid serta memberikan jasa pelayanan kepada masyarakat yang ingin menyedekahkan sebagian dananya untuk disalurkan kepada orang lain baik berupa infak, sedekah, ataupun zakat. Semakin besar sebuah masjid, semakin banyak pula jamaah masjid tersebut. Bisa jadi banyaknya jamaah suatu masjid akan mempengaruhi besarnya dana yang dikelola oleh pengurus masjid tersebut.

Ilmu manajemen keuangan merupakan ilmu yang seharusnya dimiliki oleh takmir masjid saat ini. Untuk mengelola masjid dengan baik, dibutuhkan adanya pengelolaan dana yang efektif dan efisien agar dana yang terhimpun dari masyarakat bisa 
tersalurkan dengan tepat dan cepat. Fakta di masyarakat saat ini sebagian besar takmir masjid belum memiliki kemampuan mengelola dana masjid dengan baik dan penggunaannya hanya sebatas kebutuhan internal masjid. Apablia terdapat saldo pengurus masjid cenderung menyimpan dana tersebut di bank dengan harapan mendapat imbal hasil berupa bunga. Bagi takmir masjid cara terbaik dalam mengelola dana masjid adalah dengan menyimpan dana tersebut di bank.

Manajemen keuangan masjid yang kurang maksimal menciptakan adanya fenomena dana masjid yang mengendap hingga puluhan juta khususnya masjid dengan skala besar. Dana yang seharusnya dirasakan manfaatnya masyarakat dengan segera justru mengendap di tangan takmir masjid. Keadaan seperti ini menjadikan beberapa pihak masyarakat menjadi malas untuk menyisihkan dananya ke masjid. Masyarakat memandang bahwa bersedekah secara langsung atau melalui pihak ke tiga seperti LAZ jauh lebih menjanjikan.

Mengendapnya dana masjid bukan hal yang asing bagi sebagian besar masjid saat ini. Salah satu pengurus masjid terbesar di Samarinda menyampaikan bahwa untuk saldo infak kas masjid di minggu pertama pada bulan juni 2017 sebesar Rp 35.950.000. Sangat disayangkan apabila dana masjid berjumlah puluhan juta mengendap di masjid dan tidak digunakan untuk hal yang produktif. Pihak takmir menyampaikan bahwa dana yang terkumpul dialokasikan untuk keperluan masjid. Namun dari jumlah saldo tersebut dapat disimpulkan bahwa jumlah dana yang diterima lebih besar daripada dana yang dikeluarkan.

Di desa Jotosari, kecamatan Tikung, Lamongan berdiri sebuah masjid yang unik dan berbeda dengan masjidmasjid pada umumnya. Nama masjid yang berdiri sejak 2013 tersebut adalah Masjid Namira. Sebuah masjid yang berdiri dengan megah dan berbagai fasilitas tersedia bagi para pengunjungya mulai dari lapangan parkir yang luas, wifi gratis, bahkan jamaah yang mengunjungi masjid bernuansa masjidil Haram ini mendapatkan sarapan secara gratis. Masjid ini tidak pernah sepi oleh jamaah dan berhasil membuat para pengunjungnya merasa nyaman berada di sana.

Dalam mengelola dana, takmir masjid Namira memegang teguh prinsip bahwa vang sedekah jamaah harus kembali ke jamaah secepatnya dan merasa malu ketika uang jamaah mengendap di kotak infak. Bagi mereka para pengelola masjid Namira adalah sebuah kegagalan ketika melihat saldo infak tidak nol rupiah. Walaupun di setiap periode saldo dana masjid Namira sebesar nol rupiah, takmir masjid dapat mengelola keperluan masjid dengan baik tanpa mengalami kendala sedikitpun. 
Dari uraian diatas, penulis merasa perlu melakukan penelitian tentang cara pengelolaan dana yang dilakukan oleh para pengurus masjid Namira. Sebuah fenomena unik dimana masjid berdiri dengan megah dan besarnya jumlah jamaah namun saldo yang dimiliki selalu berjumlah nol rupiah. Dalam penelitian ini penulis mengambil judul "DANA INFAK SEBAGAI PONDASI KEUANGAN MASJID NAMIRA LAMONGAN".

\section{Rumusan Masalah}

Rumusan masalah dalam penelitian ini adalah Bagaimana strategi manajemen keuangan yang dilakukan oleh takmir masjid Namira Lamongan dalam mengelola dana yang terhimpun.

\section{Tujuan Penelitian}

Untuk Untuk mengetahui dan menjelaskan bagaimana strategi manajemen keuangan yang ada di masjid Namira Lamongan. Sehingga penelitian ini berusaha menggali sistematika pengelolaan keuangan yang ada di dalam masjid Namira yang di dasarkan pada empat prinsip manajemen yaitu perencanaan, pengelompokan, pelaksanaan, dan pengendalian. Melalui hal tersebut dapat diketahui bagaimana strategi manajemen yang di terapkan hingga pengelola masjid Namira dapat menerapkan sistim zero infak.

\section{LANDASAN TEORI}

Wakaf Menurut Al-Faruq (2010:14) masjid secara bahasa berarti tempat sujud (masjidan) dan dalam keadaan yang suci. Al-Faruq mengutip beberapa hadits, antara lain dalam hadits riwayat Ahmad, Abu Dawud dan at Turmudzi dalam Shahih Al-Jami' berikut:

"bumi ini seluruhnya adalah masjid (tempat sujud), kecuali kuburan dan kamar mandi". Dan juga hadits riwayat Muslim berikut: "telah dijadikan bagi kita bumi sebagai tempat sujud dan keadaannya suci"

$$
\text { Putra (2014:13) mengutip }
$$
pendapat Syafi'ie yang menyatakan bahwa masjid adalah suatu bangunan, gedung atau suatu lingkungan yang memiliki batas yang fisik yang jelas dan didirikan secara khusus untuk beribadah umat Islam kepada Allah SWT. Fungsi masjid dalam sejarah kemunculannya, memang tidak sekedar untuk "tempat sujud" sebagaimana makna harfiahnya, tetapi multifungsi. Pada masa Rasulullah Saw, masjid berfungsi sebagai sentra kegiatan-kegiatan pendidikan, yakni tempat pembinaan dan pembentukan karakter umat. Bahkan lebih strategis, pada masa Rasulullah Saw, masjid menjadi sentra kegiatan politik, ekonomi, social dan budaya umat. Hal ini karena disetiap harinya umat Islam berjumpa dan mendengar arahan-arahan Rasulullah Saw, tentang hal ini (Kurniawan, 2014).

Manajemen adalah pemuasan kebutuhan-kebutuhan ekonomi dan sosial karena bersifat produktif bagi manusia, bagi perekonomian dan bagi masyarakat. George R. Terry mendefinisikan manajemen dengan memandangnya dari sudut proses, sebagai berikut: 
"manajemen merupakan sebuah proses yang khas, yang terdiri dari tindakantindakan yaitu, perencanaan, pengorganisasian, penggiatan, dan pengawasan, yang dilakukan untuk menentukan serta mencapai sasaransasaran yang telah ditetapkan melalui pemanfaatan sumber daya manusia sumber-sumber lainnya" (Sutarmadi, 2012: 6)

Dalam bahasa Arab, manajemen disebut dengan idarah. Adapun pengertian manajemen adalah usaha mencapai tujuan melalui kegiatan orang lain yang dilakukan oleh seorang pemimpin (Yani, 2012: 132). Dijelaskan lebih lanjut oleh Yani (2012: 133) bahwa "idarah masjid adalah suatu proses atau usaha mencapai kemakmuran masjid yang ideal, dilakukan oleh seorang pemimpin pengurus masjid bersama staf dan jamaahnya melalui berbagai aktivitas yang positif". Menurut Dewan Masjid Indonesia (2003: 33) Manajemen masjid adalah kegiatan perencanaan, pengelolaan, pengendalian yang melibatkan jama'ah masjid dan alat yang ada untuk mencapai tujuan masjid yaitu membentuk manusia bertaqwa atau insane kamil.

Pengertian keuangan masjid ialah pendanaan untuk kepentingan operasional masjid, yang didapatkan dari zakat, infak dan shadaqah, hibah, bantuan pemerintah, bantuan swasta dan usaha ekonomi, yang dijalankan oleh pengelola/pengurus masjid (Sutarmidi,
2012: 64).Ayub (1994: 64) mengatakan bahwa dalam mengelola masjid yang perlu mendapat perhatian adalah masalah keuangan dan surat menyurat. Pengurus masjid harus sungguh-sungguh dan benar-benar memperhatikan masalah ini, terutama masalah pengelolaannya. Kalau pengelolaan kevangan masjid dapat dilaksanakan secara baik, itu pertanda pengurus masjid orang-orang yang dapat dipercaya dan bertanggung jawab. Akan tetapi kalau pengelolaan keuangan masjid itu adalah orang-orang yang tidak dapat dipercaya dan tidak bertanggung jawab. Misalnya saja kevangan masjid tidak jelas penggunaannya, sementara pertanggung jawab tidak ada dan sebagainya.

\section{METODE PENELITIAN}

Penelitian ini menggunakan metodologi penelitian kualitatif. Metodologi penelitian kualitatif adalah penelitian yang mencoba memahami fenomena dalam seting dan konteks naturalnya (bukan di dalam laboratorium) di mana peneliti tidak berusaha untuk memanipulasi fenomena yang diamati (Leedy \& Ormrod 2005; Patton 2001; Sauders, Lewis \& Tornhill 2007). Penelitian ini juga menggunakan pendekatan kualitatif deskriptif. Apabila peneliti ingin mengetahui keadaan atau sesuatu mengenai apa dan bagaimana, berapa banyak, sejauh mana, dan lain-lain, maka penelitian tersebut bersifat deskriptif, 
dimana penelitian ini menjelaskan suatu peristiwa (Arikunto, 2002:30).

\section{HASIL DAN PEMBAHASAN}

\section{Perencanaan Keuangan Masjid Namira}

Perencanaan

keuangan

merupakan salah satu bagian penting yang dibutuhkan suatu lembaga dalam mengelola keuangannya. Masjid Namira dapat dikatakan sebagai masjid dengan jumlah pengeluaran di atas rata-rata apabila dibandingkan dengan masjidmasjid yang ada khususnya wilayah Lamongan. Hal ini dibuktikan dengan laporan keuangan di tahun 2017 yang menampilkan bahwa rata-rata pengeluaran masjid Namira dalam satu bulan kurang lebih 300 juta rupiah tiap bulannya. Dengan pengeluaran tersebut, pihak pengelola masjid Namira perlu adanya perencanaan keuangan yang matang. Sehingga masjid Namira dapat bertahan dan mampu melayani jamaah dengan maksimal.Dalam perencanaan keuangannya, pihak takmir beserta yayasan melakukan musyawarah bersama dalam membuat suatu keputusan. Hal ini mengarah kepada salah satu ayat di dalam al-Quran yitu surat Asy-Syura ayat 38 yang menganjurkan bagi kita untuk memutuskan suatu urusan melalui jalan musyawarah.

Berdasarkan tafsir Ibnu Katsir mengenai ayat 38 menyatakan bahwa mereka tidak pernah memutuskan sesuatu urusan melainkan terlebih dahulu mereka musyawarahkannya di antara sesamanya agar masing-masing dari mereka mengemukakan pendapatnya. Seperti dalam menghadapi urusan perang dan lain sebagainya yang penting, sebagaimana yang disebutkan dalam ayat lain melalui firman-Nya: dan bermusyawarahlah dengan mereka dalam urusan itu. (Ali Imran: 159) hingga akhir ayat.

Sehingga apa yang dilakukan para pengelola masjid Namira dalam melakukan perencanaan keuangan seusai dengan tuntunan ajaran Islam. Dengan jalan musyawarah, keputusan yang diambil dapat dilaksanakan tanpa menimbulkan adanya perpecahan dan dapat menyatukan visi yang ada. Disisi lain musyawarah dapat menjaga stabilitas kepengurusan di dalam masjid Namira serta menjaga silaturahim antar pihak baik takmir maupun yayasan.

Pengelompokan Keuangan Masjid Namira

Pengertian kevangan masjid ialah pendanaan untuk kepentingan operasional masjid, yang didapatkan dari zakat, infak dan shadaqah, hibah, bantuan pemerintah, bantuan swasta dan usaha ekonomi yang dijalankan oleh pengelola/pengurus masjid (Sutarmidi, 2012: 64). Melalui penjelasan Sutarmidi terkait pengertian keuangan masjid, kita mengetahui bahwa sumber dana masjid terdiri dari zakat, infak, shadaqah, hibah, bantuan pemerintah, bantuan swasta dan usaha ekonomi dari pengelola / pengurus masjid. 
Masjid Namira hanya memiliki satu sumber dana berupa dana infak yang terhimpun dari dua pihak yaitu jamaah dan keluarga pendiri atau yang biasa disebut dengan yayasan. Dana infak jamaah dihimpun melalui kotak infak yang diletakkan di beberapa sudut ruangan. Tidak jarang beberapa orang dari pihak yayasan menyalurkan dananya melalui kotak infak secara sembunyi-sembunyi. Selain melalui kotak infak, pihak yayasan menyalurkan dananya dengan cara transfer kepada internal pengurus masjid. Tidak ada perbedaan perlakuan terhadap dua jenis sumber dana tersebut. Hanya mengandalkan dana infak sebagai sumber dana keuangan masjid adalah sebuah hal yang berisiko tinggi. Namun fenomena ini muncul dikarenakan latar belakang dari pendirian masjid Namira yang awal mulanya adalah masjid pribadi. Seiring berjalannya waktu, jamaah masjid terus bertambah dan mendorong pendiri untuk memperluas masjid dan merubah status masjid yang semula adalah masjid pribadi menjadi masjid umum. Walaupun status masjid Namira berubah menjadi masjid umum, keyakinan bahwa segala kebutuhan masjid ditanggung oleh pendiri masih melekat kuat.

\section{Pelaksanaan Keuangan Masjid Namira}

Menurut Syamsul (2014) mengenai fungsi masjid menjelaskan bahwa dalam sejarah kemunculannya, memang tidak sekedar untuk "tempat sujud" sebagaimana makna harfiahnya, tetapi multifungsi. Pada masa Rasulullah Saw, masjid berfungsi sebagai sentra kegiatankegiatan pendidikan, yakni tempat pembinaan dan pembentukan karakter umat. Bahkan lebih strategis, pada masa Rasulullah Saw, masjid menjadi sentra kegiatan politik, ekonomi, social dan budaya umat. Hal ini karena disetiap harinya umat Islam berjumpa dan mendengar arahan-arahan Rasulullah saw.

Melalui berbagai macam kegiatannya, masjid Namira berhasil merubah masyarakat yang semula memandang masjid hanya sebagai tempat ibadah menjadi tempat yang lebih fleksibel dan nyaman untuk disinggahi dalam waktu lama. Selain kegiatannya yang beragam, masjid Namira memiliki pelayanan sangat baik terhadap jamaahnya. Hal ini diakrenakan para pengurusnya yang memiliki prinsip bahwa jamaah masjid merupakan tamu Allah.Prinsip tersebut tidak hanya dituangkan melalui sikap ramah terhadap jamaah, tetapi juga dengan fasilitasfasilitas yang diberikan mulai dari parfum khas masjidil Haram yang di impor langsung dari madinah, kolam ikan, sajadah yang nyaman, hingga kiswah yang terpampang megah di depan ruangan masjid.

Al-Faruq (2010: 240) menjelaskan mengenai prosedur pengeluaran masjid bahwa Setiap pengeluaran dana perlu diperhatikan adanya kesesuaian dengan anggaran yang telah ditetapkan bagi 
masing-masing bidang. Bidang yang bersangkutan mengajukan permohonan dana kepada Ketua Umum dengan mengisi Form Permintaan Uang Muka. Apabila disetujui, selanjutnya bendahara mengeluarkan dana sesuai yang dimintakan. Demikian pula, penggunaan dana tersebut dipertanggungjawabkan dengan mengisi

Form Pertanggungjawaban Uang Muka. Setiap pemasukan dan pengeluaran hendaknya disertai dengan bukti tertulis meskipun hanya sekedar catatan kecil. Khusus untuk pengeluaran, bidang kerja yang mempergunakan dana hendaknya memberikan bukti penggunaan dana, baik dalam bentuk kuitansi, nota, kupon, dan sebagainya. Bukti-bukti ini diserahkan kepada bendahara bersamaan dengan Laporan Pertanggungjawaban.

Masjid Namira memiliki sistem laporan keuangan yang berbeda dengan teori di atas. Jika menurut teori yang disampaikan Al-Faruq bahwa bidang yang bersangkutan perlu mengajukan permohonan dana dan melakukan beberapa kegiatan administrasi, maka hal tersebut tidak berlaku di masjid Namira. Setiap pengeluaran yang akan dilakukan, masjid namira hanya perlu memusyawarahkan dengan pihak yayasan. Untuk laporan pertanggung jawaban, cukup dengan laporan pengeluaran yang dibuat oleh bendahara dari pihak yayasan yang sekaligus sebagai takmir masjid. Hal ini dapat berjalan dikarenakan struktur pengurus masjid Namira yang terdiri dari pihak takmir dan yayasan di setiap bidangnya sehingga keputusan yang dilakukan dapat dilaksanakan dengan cepat.

Laporan kevangan memuat dua jalur: pemasukan dan pengeluaran uang. Dengan sekilas pandang, laporan itu akan menjelaskan dari mana saja sumber vang diperoleh dan untuk apa saja uang itu dipergunakan. Jumlah selisih antara keduanya, atau saldo--hasilnya mungkin minus alias tekor, mungkin pula plus alias ada tabungan--menjelaskan posisi kevangan masjid. Kenyataan di banyak masjid memperlihatkan hampir tak ada saldo minus. Pada umumnya saldo itu bernilai plus, yang semakin lama semakin besar. Ini kalau masjid benar-benar dikelola secara baik dan tertib (Ayub, 1994: 65).

Fakta di masjid Namira sedikit berbeda dengan apa yang disampaikan oleh teori di atas. Saldo yang ditampilkan baik dalam laporan umum maupun khusus selalu nol yang artinya antara pengelvaran dan pemasukan seimbang. Takmir masjid Namira selalu memastikan saldo yang dimiliki harus nol. Metode yang digunakan dalam melakukan hal tersebut adalah dengan cara melakukan pengeluaran melebihi jumlah dana infak yang terhimpun dari jamaah dan menjadikan dana yayasan sebagai penutup atas kekurangan dana infak tersebut. Walaupun dikatakan melakukan pengeluaran melebihi jumalah dana infak, 
yang sebenarnya terjadi adalah dana infak yang terhimpun dari jamaah tidak mampu menutupi kebutuhan masjid Namira.

\section{Pengendalian Keuangan Masjid Namira}

Pada umumnya masjid menjaga likuiditas keuangannya dengan cara mendepositkan dananya ke dalam rekening bank agar dana yang telah terhimpun dapat tersimpan dengan aman dan dapat berkembang melalui sistim bunga atau bagi hasil apabila rekening yang digunakan adalah bank syariah. Sehingga seandainya ada kebutuhan secara mendadak, takmir dapat menangani melalui dana yang telah di simpan di bank. Al-Faruq (2010: 240) menyampaikan bahwa apabila dana yang terhimpun akan disimpan ke dalam bank sebaiknya menggunakan bank Syariah. Hal ini dikarenakan di dalam bank Konvensional terdapat sistim bunga yang merupakan salah satu bentuk dari riba.

Namun seperti yang dijelaskan pada pembahasan sebelumnya bahwa mekanisme pendayagunaan dana masjid Namira adalah melakukan pengeluaran lebih dari jumlah dana infak yang terhimpun dan menjadikan dana dari yayasan sebagai penutup atas kekurangan yang ada. Sehingga dari hal masjid Namira tidak melakukan penyimpanan dana dikarenakan dana yang terhimpun langsung di alokasikan secara maksimal tanpa sisa.Untuk dapat mendayagunakan dana infak secara efektif dan menghindari risiko likuiditas dana infak, takmir masjid Namira melakukan perhitungan dana kotak infak setiap dua minggu sekali. Hal ini dilakukan karena besarnya jumlah dana infak yang berhasil dihimpun oleh masjid Namira.

Menjadikan yayasan sebagai titik tumpu keuangan masjid Namira sama halnya dengan mengumpulkan segala macam risiko di satu titik yaitu pihak yayasan. Kesuksesan dan kelancaran masjid Namira dalam operasionalnya bergantung pada yayasan dikarenakan dana infak jamaah sendiri tidak mampu menutupi kebutuhan operasional masjid Namira yang begitu besar. Apabila pihak yayasan mengalami penurunan keuangan dan tidak dapat menutupi kekurangan dana infak dalam memenuhi kebutuhan operasional maka masjid Namira akan mengalami penurunan baik dari segi program kegiatan maupun fasilitas yang ada.

Tidak ada penanganan khusus dalam menghadapi risiko likuiditas tersebut. Namun yang menjadikan pengurus masjid terutama bapak H. Helmy Reza tetap istiqomah dalam mengembangkan masjid Namira adalah prinsip yang mereka pegang.Dengan memegang prinsip bahwa segala yang dilakukan karena Allah maka Allah akan membantu segala urusannya, sosok penggagas masjid Namira tersebut memikul risiko dan terus berjuang dalam mengembangkan masjid Namira dengan keyakinan bahwa Allah yang akan membantu dalam perjuangannya. 


\section{KESIMPULAN}

Pengelolaan keuangan masjid Namira dilakukan oleh dua pihak yakni takmir dan yayasan selaku keluarga pendiri masjid Namira dalam bentuk struktur organisasi yang di setiap bidangnya terdiri dari dua pihak tersebut.Pendayagunaan dana infak di masjid Namira bukanlah menjadikan nol saldo dana infak, melainkan kebutuhan operasional masjid yang terlalu besar dibandingkan dengan pemasukan dana infak dan menggunakan dana yayasan sebagai penutup atas kekurangan tersebut. Tidak ada perencanaan khusus untuk menangani risiko likuiditas apabila kevangan kelvarga pendiri mengalami masalah. Hanya prinsip bahwa segala sesuatu yang dilakukan karena Allah maka Allah akan membantu segala kebutuhannya sebagai modal dalam menghadapi risiko tersebut.

pengelolaan wakaf produktif di Yayasan Baitur Rahma Sejahtera terdapat 8 jenis risiko yang terdidentifikasi yaitu terdiri dari risiko operasional, risiko kepatuhan syariah, risiko investasi, risiko pasar, risiko bisnis, risiko kehilangan wakif, risiko reputasi, dan risiko pendistribusian asset wakaf dari 8 jenis risiko tersebutterdapat 17 jenis uraian risiko. Hasil yang diperoleh dari penilaian risiko menghasilkan Level Tinggi sebanyak 4 jenis uraian risiko, Level Signifikan sebanyak 6 jenis uraian risiko, Level Moderat sebanyak 3 jenis uraian risiko dan Level Rendah sebanyak 4 jenis uraian resiko.

\section{Daftar Pustaka}

Al-Faruq, A. (2010). Panduan Lengkap Mengelola dan Memakmurkan Masjid. Solo: Pustaka Arafah.

Al-Fauzan, A. (2008). Fiqih Seputar Masjid. Jakarta: Pustaka Imam Asy-Syafi'i.

Ayub, M. (1996). Manajemen Masjid. Jakarta: Gema Insani.

Daft, Richard L. (2002). Manajemen Edisi Kelima Jilid I. Jakarta: Erlangga

Dewan Masjid Indonesia. (2003). Buku Panduan Praktis Manajemen Pengelolaan Masjid Edisi Pertama. Surabaya: PW DMI Jawa Timur

Gazalba, S. (1975). Masjid Pusat Ibadat dan Kebudayaan Islam.Jakarta : Pustaka Antara.

Kasmir. 2010. Pengantar Manajemen Keuangan. Jakarta: Kencana Prenada Media Group

Kurniawan, S. ( 2014). Masjid dalam Lintasan Sejarah Umat Islam. Jurnal Khatulistiwa, Vol. IV/ No.2/ September 2014

Munawir, S. 2007. Analisis Laporan Keuangan. EdisiKedua. Yogyakarta : Liberty.

Muslim, A. (2004). Manajemen Pengelolaan Masjid. Jurnal Aplikasi Ilmu-ilmu Agama Vol. V/ No. 2/ Desember 2004

Musthofa, T. (2010). Upaya Menghidupkan Kembali Risalah Masjid Seperti Zaman Rasulullah. Jurnal Ulama, (online), Tahun III/ Vol.III/ No.1/ 
April2010, (http://isjd.pdii.lipi.go.id, diakses 10 Desember 2017)

Putra, M. Vithro H.( 2014). Preferensi Takmir Masjid dalam Memilih Layanan Perbankan di Surabaya (A Qualitative Multiple Case Study di Delapan Masjid). Surabaya: Universitas Airlangga

Riyanto, B. (2001). Dasar-Dasar Pembelanjaan Perusahaan. Yogyakarta: BPFE Yogyakarta

Shiu, YM. 2004. Determinants of United Kingdom General Insurance Company Performance. British Actuarial Journal, vol. 10, pp. 1079 -1110 ,

Sochimin (2015). Praktik Manajemen Kevangan Masjid. Purwokerto: IAIN Purwokerto
Sudana, I Made. 2009. Manajemen Keuangan: Teori dan Praktik. Surabaya: Airlangga University Press.

Sutarmadi, A. (2012). Manajemen Masjid Kontemporer. Jakarta: Penerbit Media Bangsa.

Sutrisno, (2003). Manajemen Keuangan (Teori, Konsep, dan Aplikasi). Yogyakarta: Ekonisia.

Syamsuddin. 2009. Manajemen Keuangan Perusahaan. Jakarta:PT.Raja Grafindo Persada

Weston, J. Fred dan Thomas E. Copeland, (1999). Manajemen Kevangan, Jakarta: Penerbit Erlangga.

Yani, A. (2012). Panduan Memamkmurkan Masjid. Jakarta: Khairu Ummah. 